\title{
DEVELOPMENT OF THE INTERURBAN SERVICE BY USE OF ALTERNATIVE COMMERCIAL ROAD TRAINS
}

\author{
Oleg Pocklad \\ Motor Transport Management Division, State University of Management, Moscow, Russia, \\ Phone +7(495) 922-38-91. E-mail: OPoklad@yandex.ru
}

Received 21 July 2006; accepted 1 February 2007

\begin{abstract}
The main task of this paper is to review the principal aspects in organization of interurban long haul service by use of road trains on the basis of the "district" traffic system. The goal of the paper is to determine the most effective methods of trucking operations in order to highlight the regularities that characterize these methods. The paper describes practicable methods of freight flow analysis, some factors and parameters concerning movement of motorvehicle trains and original route schedules as well. Of special interest is the obtained algorithm of economically effective trucking operations of motor-vehicle trains on the route.
\end{abstract}

Keywords: through system, district system, truck (hybrid) tractor, detachable semi-trailer, route section (district), tractor maneuvering turnaround, packet schedule.

\section{Introduction}

It is a matter of general experience that freight flow and its parameters, such as hauling capacity, freight distribution, configuration of separate traffic currents, time and trend stability form the backbone of the transport traffic organization.

Although we realize that the freight flow analysis is not so easy when there is a lot of companies with individual business approach, this problem is absolutely realistic since you can find everywhere the enterprises with a continuous production cycle which always requires a regular freight-exchange between the production sphere and the sphere of distribution and consumership (raw materials - semifinished products manufactured goods; for instance, suppliers - manufacturing plants - consumers - assembly plants, textile integrated mills - clothing manufacture, etc.) [1].

Mutually cooperating enterprises, plants, factories, markets and their warehouses are located very often at a considerable distance from one another, therefore, the initial phase of the freight flow analysis consists in revealing the transport-economic contacts as a result of which the matrix of regular freight exchange by means of road trains is obtained (Table 1).

Nowadays, most of the countries employ the socalled "through" system of the line-haul trucking operations (transscheduled run) that conceals the true picture of forming the organized goods traffic since each motor-vehicle train (and the whole trucking company) fulfils its tasks of freight delivery independently and periodically Fig 1 a).

At first glance such a self-sufficient system is very attractive due to its simplicity, but it has a lot of negati- ve consequences such as poor control of movement of motor-vehicle trains on the route, absence of distinct supply chain, relatively low speed of freight delivery, hard conditions of article for drivers, high degree of traffic accidents and so on.

The suggested "district" trucking system is more progressive since it eliminates all shortcomings of the through system and has certain advantages (Fig 1 b) first of all in normalizing the freight delivery. The traffic of the road trains in the district trucking system can be organized by any enterprise of sufficient power public transport agency or private company irrespective of its social status.

This system is based on the motor-vehicle trains composed of truck (hybrid) tractors and quickdetachable semi-trailers, i.e. the quick-detachable semitrailers are detached from the truck tractors. The semitrailers are handed over to the other truck tractors as "the relay baton" at the joints of district (road sections), forming a kind of motor transport conveyer for both inbound and outbound journeys.

Thus, the district transportation system is connected with two interdependent turnaround systems - of trucks and semi-trailers. Trucks move within the limits of their districts and semi-trailers cover all route from the initial to the terminal point of destination. In most cases, movement of motor-vehicle trains is not delayed en route and the final delivery of semi-trailers is accomplished by special maneuvering trucks.

The district trucking system also has economic advantages since the operational costs in the through system make a sharp rise within the range of productive run of motor-vehicle trains and its hauling capacity (Fig2). Analyzing the freight flows of the line-haul 
Table 1. Constant freight-exchange of trucking terminals

(tons per day)

\begin{tabular}{|c|c|c|c|c|c|c|c|c|}
\hline \multirow{2}{*}{$\begin{array}{c}\text { Arrival } \\
\text { Departure }\end{array}$} & \multicolumn{7}{|c|}{ Trucking terminals } & \multirow[t]{2}{*}{ Total } \\
\hline & $\mathbf{A}$ & B & $\mathbf{C}$ & D & $\mathbf{E}$ & $\mathbf{F}$ & $\mathbf{N}$ & \\
\hline $\mathbf{A}$ & & $\mathbf{1 0 0}^{185}$ & $150^{240}$ & $200^{320}$ & $100^{315}$ & $100^{290}$ & $200^{186}$ & 850 \\
\hline B & $100^{185}$ & & $200{ }^{290}$ & $200{ }^{410}$ & $300^{170}$ & $150^{310}$ & $100^{215}$ & 1050 \\
\hline $\mathrm{C}$ & $150^{240}$ & $100^{290}$ & & $3000^{170}$ & $100^{360}$ & $100^{480}$ & $200^{380}$ & 950 \\
\hline D & $100^{320}$ & $200^{410}$ & $300^{170}$ & & $100^{400}$ & $150^{580}$ & $100^{345}$ & 950 \\
\hline $\mathbf{E}$ & $150^{315}$ & $150^{170}$ & $100^{360}$ & $100^{400}$ & & 2005 & $200^{470}$ & 900 \\
\hline $\mathbf{F}$ & $2000^{290}$ & $200^{310}$ & $200^{480}$ & $100^{580}$ & $100^{520}$ & & $150^{230}$ & 950 \\
\hline $\mathbf{N}$ & $300^{186}$ & $100^{2 / 5}$ & $300^{380}$ & $100^{345}$ & $100^{470}$ & $100^{230}$ & & 1000 \\
\hline Total & 1000 & 850 & 1250 & 1000 & 800 & 800 & 950 & 6650 \\
\hline $\begin{array}{ll}\text { - } & \mathbf{T} \mathrm{km} ; \\
\text { - } & \text { random }\end{array}$ & 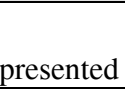 & ple) & & & & & & \\
\hline
\end{tabular}

transport, first of all, it is necessary to pay attention to the structure of cargoes in this region. It facilitates the problem of proper choice of the required rolling stock. In the central region of Russia, all freights were distributed into following groups: industrial $(55 \%)$, trade $(20 \%)$, building $(17 \%)$, agricultural $(16 \%)$, other (container, strategic, high value goods, etc. - $2 \%$ ) [2].

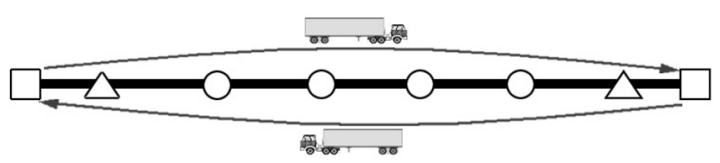

a)

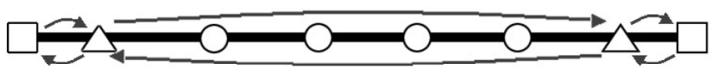

b)

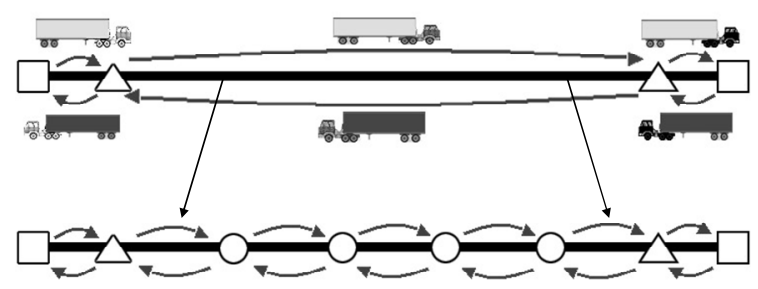
$\triangle$ - trucking terminals
$\square$ - customers (consignees and consigners)
- interurban transport points (changing grounds)

Fig 1. Interurban long haul service with use of road trains: a - "through system"; b - "district system"

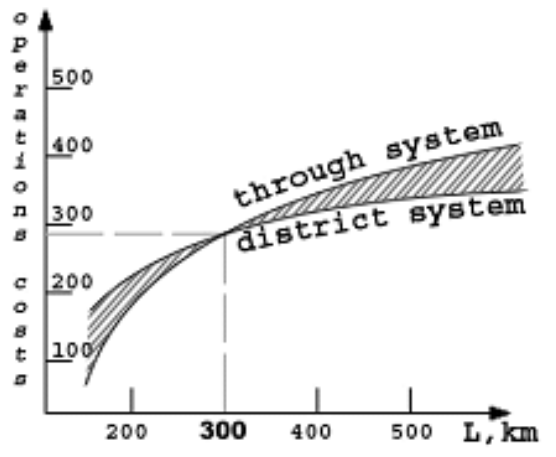

a)

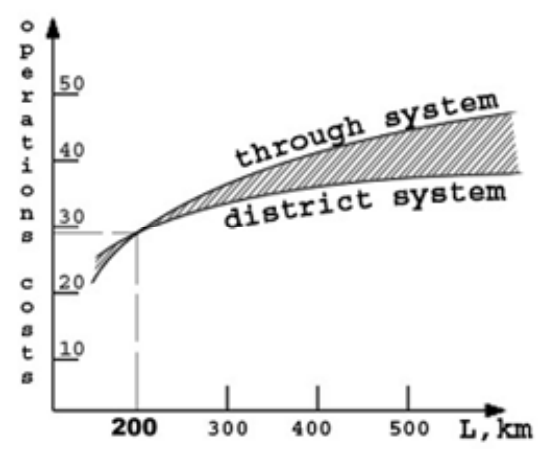

b)

Fig 2. Comparative costs of "through" and "district" traffic systems depending on volume of transportation: a - operational costs (thousands of rubles), 100 tons/day; $\mathrm{b}$ - operational costs (millions of rubles), 1000 tons/day 


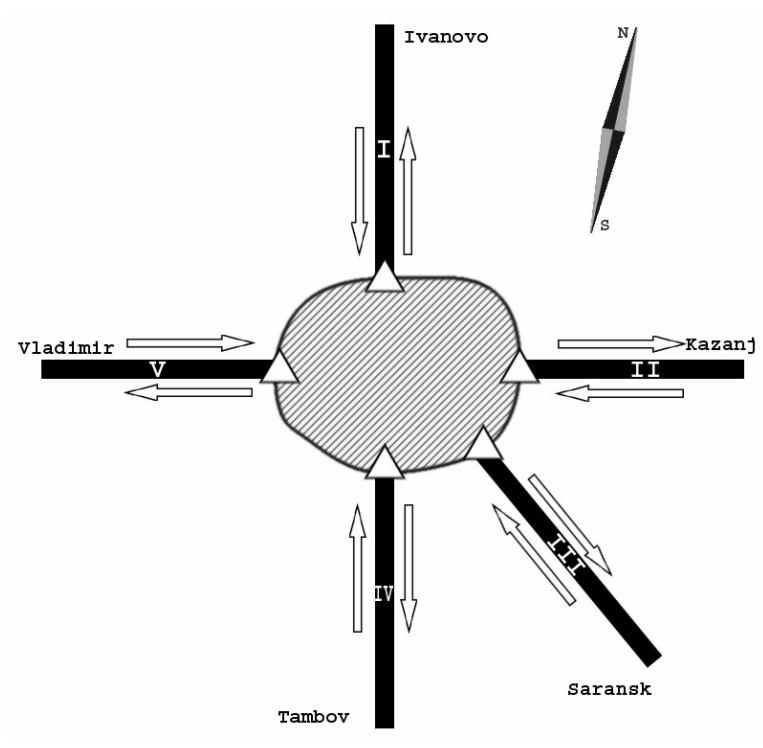

$\triangle$ - trucking terminals

Fig 3. Vehicular transport hub (N. Novgorod`s hub terminals )

In the examined region, the network of heavy freight traffic and its main routes have been determined and formed clearly. This network is based on the transport centers with different economic potential Fig 3). Of course, the freight tension is higher in those centers, where several arterial roads (of latitudinal, meridian and diagonal trends) cross.

The closer the traffic centre to the hypothetic center of the examined region, the greater is the freight traffic volume because more transport points are forwarding goods through it (Table 2 a). The employment of the corresponding rolling stock will make it possible to transform the freight flow into the truck flows through the same traffic center (Table $2 \mathrm{~b}$ ). Presenting these tables the author wants to attract one's attention not so much to the content of the tables but mostly to the procedure of processing the freight flows. Thus considering the order for the west direction of the traffic center it is important to determine regular freight flows not only from the adjacent traffic center but all cargoes coming from this direction (from Baltic region, Ukraine, Byelorussia and Russian towns) and settling here or going transit. Other directions are considered in a similar way. The opposite trends are considered in the same way [3].

\section{Factors and parameters used for organizing truck traffic}

Upon determining the stable number of daily scheduled runs in one direction, we can start organizing the traffic of road trains. The main idea is to use a minimum quantity of trucks and semi-trailers with their high hauling efficiency. The effective organization of traffic on the operating line-haul can not be realized without taking into account all traffic conditions determined by objective factors and basic parameters in different combinations depending on the operation situation.

Table 2. Arrival-departure of freights and road trains through transport hub (N. Novgorod)

a - Freights arrival-departure (in thousand tons, 2000)

\begin{tabular}{|c|c|c|c|c|c|c|c|c|c|c|c|}
\hline \multicolumn{6}{|c|}{ ARRIVAL } & \multicolumn{6}{|c|}{ DEPARTURE } \\
\hline \multirow{2}{*}{$\begin{array}{l}\text { from the } \\
\text { direction }\end{array}$} & \multicolumn{3}{|c|}{ to the junction } & \multirow{2}{*}{ transit } & \multirow{2}{*}{ Total } & \multicolumn{3}{|c|}{ from the junction } & \multirow{2}{*}{ transit } & \multirow{2}{*}{ total } & \multirow{2}{*}{$\begin{array}{c}\text { to direc } \\
\text { tions }\end{array}$} \\
\hline & center & periphery & in all & & & center & periphery & in all & & & \\
\hline I & 52 & 16 & 68 & 249 & 317 & 97 & 67 & 164 & 210 & 374 & I \\
\hline II & 13 & 7 & 20 & 20 & 40 & 6 & 5 & 11 & 27 & 38 & II \\
\hline III & 47 & 18 & 65 & 230 & 295 & 66 & 26 & 92 & 262 & 354 & III \\
\hline IV & 40 & 20 & 60 & 15 & 75 & 35 & 11 & 46 & 14 & 60 & IV \\
\hline V & 22 & 14 & 36 & 24 & 60 & 25 & 13 & 38 & 25 & 63 & V \\
\hline Total & 174 & 75 & 249 & 538 & 787 & 229 & 122 & 351 & 538 & 889 & Total \\
\hline
\end{tabular}

b - Truck flows through the same transport hub (unit/day, 2000)

\begin{tabular}{|c|c|c|c|c|c|c|c|c|c|c|c|}
\hline \multicolumn{6}{|c|}{ ARRIVAL } & \multicolumn{6}{|c|}{ DEPARTURE } \\
\hline \multirow{2}{*}{$\begin{array}{l}\text { from the } \\
\text { direction }\end{array}$} & \multicolumn{3}{|c|}{ to the junction } & \multirow{2}{*}{ transit } & \multirow{2}{*}{ Total } & \multicolumn{3}{|c|}{ from the junction } & \multirow{2}{*}{ transit } & \multirow{2}{*}{ total } & \multirow[b]{2}{*}{ o directions } \\
\hline & center & periphery & in all & & & center & periphery & in all & & & \\
\hline I & 22 & 16 & 38 & 81 & 119 & 53 & 4 & 57 & 70 & 127 & I \\
\hline II & 7 & 3 & 10 & 7 & 17 & 4 & 6 & 10 & 9 & 19 & II \\
\hline III & 21 & 7 & 28 & 75 & 103 & 30 & 6 & 36 & 84 & 120 & III \\
\hline IV & 20 & 6 & 26 & 5 & 31 & 15 & 3 & 18 & 5 & 23 & IV \\
\hline V & 11 & 4 & 15 & 8 & 23 & 12 & 5 & 17 & 8 & 25 & $\mathbf{V}$ \\
\hline TOTAL & 81 & 36 & 117 & 176 & 293 & 114 & 24 & 138 & 176 & 314 & TOTAL \\
\hline \multicolumn{12}{|c|}{$\begin{array}{l}\text { - } q=20 \mathrm{t} \text { - average value (freight of the } 1 \text { st and } 2 \text { nd class); } \\
\text { - the load factor } \gamma=0.85 ; \\
\text { the full load run factor } \beta=0.9\end{array}$} \\
\hline
\end{tabular}


The former ones can be presented by the following outer circumstances:

$Q$ - average daily freight flow;

$q$ - nominal (certificate) load-carrying capacity of motor-vehicle train;

$\gamma$ - load factor;

$n=\frac{Q}{q \times \gamma}-$ amount of daily truck scheduled runs;

$V_{t}$ - average normalized (rated) truck speed;

$L$ - route length;

$m$ - number of route sections;

$t_{W}-$ duty time of warehouses.

The parameters include:

$T_{d}$ - time of the truck movement on the route section;

$i_{d}$ - time intervals between truck scheduled runs (timed delivery slot);

$t_{s t}$ - standing time of truck at the route points;

$t_{m}$ - normalized (rated) turnaround time of the maneuvering truck;

$\sum \omega$ - full turnarounds of all semi-trailers;

$w_{i}$ - dwell time of semi-trailers at the initial point of the route (at the terminal);

$w_{f}$ - dwell time of semi-trailers at the final point of the route (at the terminal);

Both $w_{i}$ and $w_{f}$ include time of the maneuver turnaround of semi-trailer compounded with maneuvering truck and time of waiting of line-haul truck $\left(t_{m}+t_{\text {wait }}\right) n \longrightarrow>; t \underset{\text { waiting }}{\longrightarrow} 0$.

Coefficient of requirement of semi-trailers $N_{t}$ for one truck $A_{t}$ gives a numerical estimation of the rolling stock:

$$
\eta=\frac{N_{t}}{A_{t}}
$$

\section{Schedules of road train traffic}

The schedule of road train traffic or the coordinated article plan of operation of the rolling stock is the principal condition for rhythmical operation of the cargo delivery system. Let us illustrate the interaction of factors and parameters by an example of one of three types of schedules, the so-called "packet" schedule, for which the time interval between the scheduled runs of trucks is a relatively constant value. For other types of schedules this value is variable. The length of the route section can be presented by the formula:

$$
L_{m}=T_{d} \times V_{T} .
$$

In other words, the distance between two points of the route may be presented, as:
$L_{m}=240 \mathrm{~km}=3 \mathrm{~h} \times 80 \frac{\mathrm{km}}{\mathrm{h}}=4 \mathrm{~h} \times 60 \frac{\mathrm{km}}{\mathrm{h}}=5 \mathrm{~h} \times 48 \frac{\mathrm{km}}{\mathrm{h}}$.

Let me remind you, that $V_{T}$ - speed of the truck movement is a value rated and connected with traffic timetable). It should be noticed, that $T_{d}=4 \mathrm{~h}$ is optimal for trucker's driving. Standing time of truck $t_{s t}$ allows $1 \mathrm{~h}$. It is quite enough for semi-trailers to be reattached and for short-term relaxation for drivers. Timed delivery slot is $1 \mathrm{~h}$ as well. The turnaround time of the maneuvering road train is $4 \mathrm{~h}$. The duty time of warehouses is $t_{W}=24 \mathrm{~h}$. The cargo scheduled runs section is 1 shuttle.

And so, let us take:

$$
\begin{aligned}
& T_{d}=4 \mathrm{~h} ; i_{d}=1 \mathrm{~h} ; t_{s t}=1 \mathrm{~h} ; t_{m}=4 \mathrm{~h} ; \\
& t_{w}=24 \mathrm{~h}, m=1 .
\end{aligned}
$$

Let us designate the axis of ordinate (i.e. route axis) via the time vector $\left(T_{d} \times V_{t}\right)$, and then we obtain the following dependences and trucking traffic schemes.

A scheme (see Fig 4 a):

$$
1 \leq n<\frac{t_{m}}{i_{d}}
$$

At one delivery per day ( $n=1)$ a truck delivering a semi-trailer from terminal $\mathrm{A}$ to terminal $\mathrm{B}$ returns to its initial point with a (reserve) semi-trailer prepared beforehand, and the semi-trailer delivered to point $\mathrm{B}$ stays there for a period of $\left(24+t_{s t}\right)$.

In this case, dwell time of the semi-trailers at the initial terminal:

$$
w_{i}=n\left(24-2 T_{d}-t_{s t}\right) \text {. }
$$

The total time of movement of the semi-trailers with line-haul trucks en route:

$$
\sum T_{d}=2 n \cdot T_{d} \text {. }
$$

Dwell time of the semi-trailers at the final terminal:

$$
w_{f}=n\left(24+t_{s t}\right) \text {. }
$$

The number of semi-trailers:

$$
N_{t}=\frac{\sum w}{24}=\frac{w_{i}+2 n \cdot T_{d}+w_{f}}{24}=2 n
$$

is determined by the duration of their turnarounds, including the traffic time and the dwell time at the terminals.

B scheme (see Fig 4 b):

$$
\frac{t_{m}}{i_{d}} \leq n \leq \frac{2 \cdot T_{d}+t_{m}+t_{s t}}{i_{d}}
$$


When the number of dispatched trucks is equal $n=\frac{t_{m}}{i_{d}}$ a semi-trailer delivered first from point $A$ to point $B$, and the following one also, have sufficient time for the maneuvering turnaround. The other semi-trailers within this range of dispatches also have the maneuvering turnaround.

In this case, dwell time of the semi-trailers at the initial terminal:

$$
w_{i}=n\left(24-2 T_{d}-t_{s t}\right) .
$$

The total time of movement of the semi-trailers with line-haul trucks en route:

$$
\sum T_{d}=2 n \cdot T_{d} \text {. }
$$
nal:

Dwell time of the semi-trailers at the final termi-

$$
\begin{aligned}
& w_{f}=\left(i_{d} \cdot n-t_{m}+t_{s t}\right) \cdot \frac{t_{m}}{i_{d}}+ \\
& \left(\frac{t_{m}-t_{s t}}{i_{d}}\right) \cdot\left(24-i_{d} \cdot n+t_{m}\right) .
\end{aligned}
$$

The number of semi-trailers:

$$
N_{t}=\frac{\sum w}{24}=\frac{\left(i_{d} \cdot n+t_{m}-t_{s t}\right)}{i_{d}} .
$$

C scheme (see Fig 4 c):

$$
\frac{2 \cdot T_{d}+t_{m}+t_{s t}}{i_{d}}<n \leq \frac{24}{i_{d}} .
$$

In this range beginning with a certain number of dispatches of road trains (" $n$ "), the trailers that have managed to make the maneuvering turnaround may also appear at the initial point of the route (terminal $A$ ).

In this case, dwell time of the semi-trailers at the initial terminal:

$$
\begin{aligned}
& w_{i}=\left(i_{d} \cdot n-2 T_{d}-t_{m}-t_{s t}\right) \cdot \frac{t_{m}}{i_{d}}+ \\
& \left(\frac{2 T_{d}+t_{m}+t_{s t}}{i_{d}}\right) \cdot\left(24-i_{d} \cdot n+t_{m}\right) .
\end{aligned}
$$

The total time of movement of the semi-trailers with line-haul trucks en route:

$$
\sum T_{d}=2 n \cdot T_{d} .
$$

Dwell time of the semi-trailers at the final terminal (point $B$ ):

$$
\begin{aligned}
& w_{f}=\left(i_{d} \cdot n-t_{m}+t_{s t}\right) \cdot \frac{t_{m}}{i_{d}}+ \\
& \left(\frac{t_{m}-t_{s t}}{i_{d}}\right) \cdot\left(24-i_{d} \cdot n+t_{m}\right) .
\end{aligned}
$$

The number of semi-trailers:

$$
N_{t}=\frac{\sum w}{24}=\frac{2 \cdot\left(T_{d}+t_{m}\right)}{i_{d}}=\text { const } .
$$

The number of trucks:

$$
A_{t}=\frac{2 \cdot\left(T_{d}+t_{s t}\right)}{i_{d}}=\text { const } \text {. }
$$

a) $n=1 ; 1 \leq n<\frac{t_{m}}{i_{d}}$

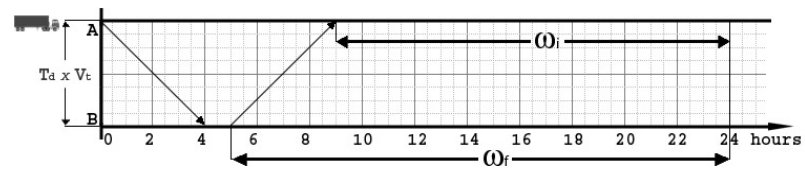

b) $n=4 ; \frac{t_{m}}{i_{d}} \leq n \leq \frac{2 T_{d}+t_{m}+t_{s t}}{i_{d}}$

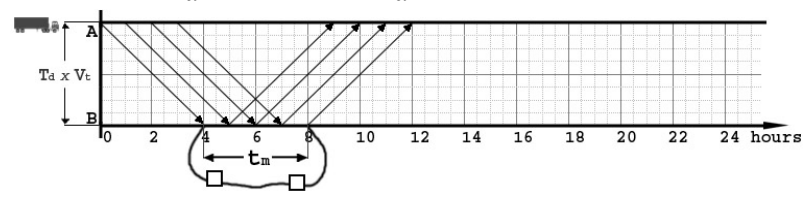

c) $n=14 ; \frac{2 T_{d}+t_{m}+t_{s t}}{i_{d}}<n \leq \frac{24}{i_{d}}$

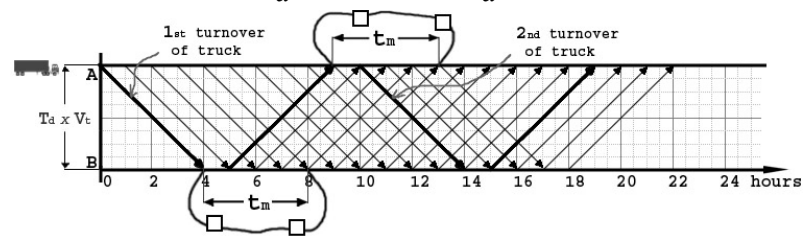

d) $n=1 ; m=2 ; t_{w}=16 \mathrm{~h}$

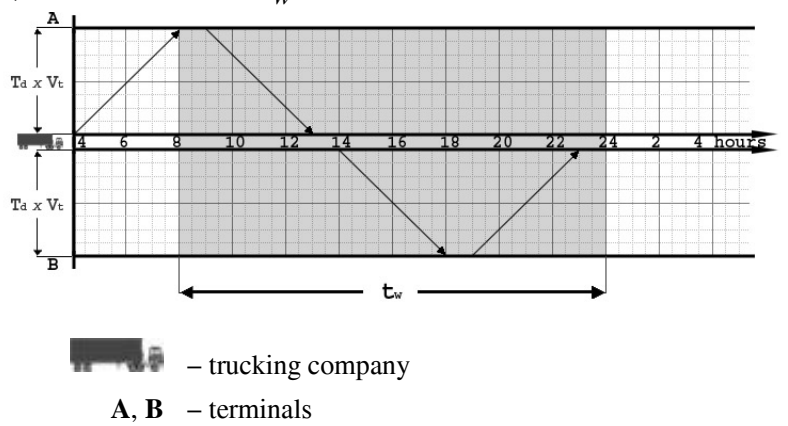

Fig 4. "Packet" traffic schemes

When the number of daily scheduled runs reaches certain (critical) value $\left(n_{c r}\right)$ (in our case $n=14$ ) it can be called the zone in which further increase in the traffic flow (or the number of scheduled runs) does not require increase in the number of trucks and semitrailers (Fig 5).

Summing up these three components, at any meaning of " $n$ " (14-24) in our case, the reader will obtain a constant value $(384 / 24)$ or 16 semi-trailers. The operators may take any meaning of " $n$ " and change above factors and parameters from their own version, the result will be the same. The author would like to attract special attention to this phenomenon because this is the key for solving the problem of cutting short the rolling stock at the increasing scopes of delivery ("effect of shuttle"). The number of trucks also becomes constant. 


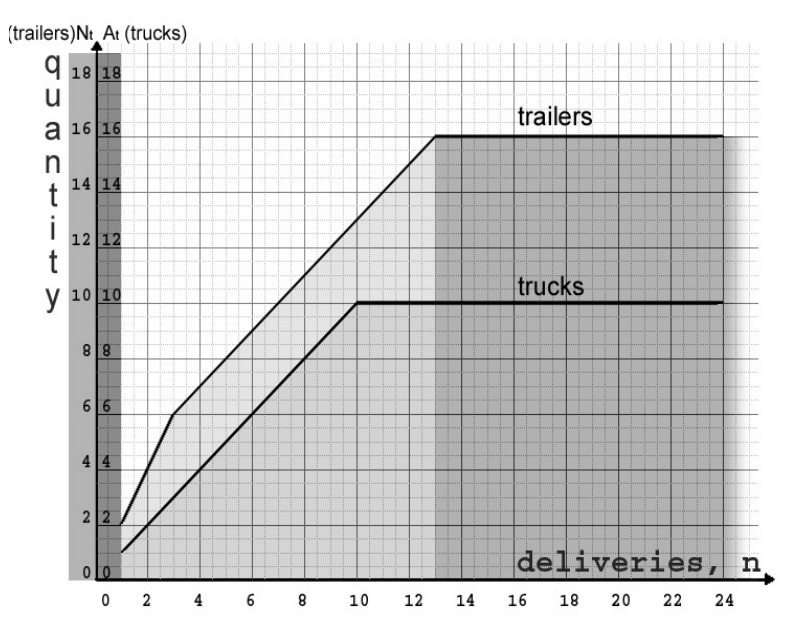

Fig 5. Profitable field of trucking operations:

$T_{d}=4 \mathrm{~h} ; t_{m}=4 \mathrm{~h} ; t_{s t}=1 \mathrm{~h} ; i_{d}=1 \mathrm{~h} ; t_{w}=24 \mathrm{~h}$

Within this zone each truck, beginning with " $n_{\text {critical }}$ " (in our case $n=10$ ), performs another turnaround within this route section, i.e. the route time of each truck is $16 \mathrm{~h}$ and the load run is $16 \mathrm{~h} \cdot V_{t}$.

Varying the interval of dispatching the trucks, i.e. compacting or expanding the "packet-system", by using the trucks of higher load-carrying capacity, or by dispatching the trucks by "stringet" standard schedule (when $i_{d}=1 \mathrm{~h}$ ) one after another (in practice it can be $i_{d}=5-10 \mathrm{~min}$ ) the zone may retain operational control. The main factors here are the volume of freight flow and the structure of the transportation motor pool.
In case of passive control of operation of the rolling stock, we find ourselves in the other type of schedule, when $n>\frac{24}{i_{d}}$. The second and third types of the schedules which have their own regularities and specific features are not considered here, like the optimum location of terminals, trucking companies, grounds for changing trucks and other facilities along the route.

It should be pointed out that these regularities are preserved for the increase in number of route sections when the route consists of adjacent sections of different length and different duty time of customer's warehouses $\left(t_{w}=24 \mathrm{~h}, t_{w}=16 \mathrm{~h}, t_{w}=8 \mathrm{~h}\right)($ Fig $4 \mathrm{~d})$.

In general case, when the route includes " $m$ " sections:

$$
\begin{aligned}
& N_{t}=n \frac{\left(w_{i}+2 \cdot T_{d} \cdot m+2 \cdot t_{s t} \cdot(m-1)+w_{f}\right)}{24 \cdot i_{d}} ; \\
& A_{t}=\frac{m \cdot n}{2} .
\end{aligned}
$$

The next stage of our research deals with the choice of the most cost-effective motor-vehicle train from the range of the large trucks and semi-trailers by use of equivalent truck loading table (Table 3 ).

It is commonly supposed that the motor-vehicle train with the highest load-carrying capacity is considered to be most effective. In the majority of cases it is actually so but different combinations of the above factors, parameters and schedules may drastically change this stereotype. The economic evaluation can be made by using the suggested model (Fig 6).

Table 3. Equivalent truck loading

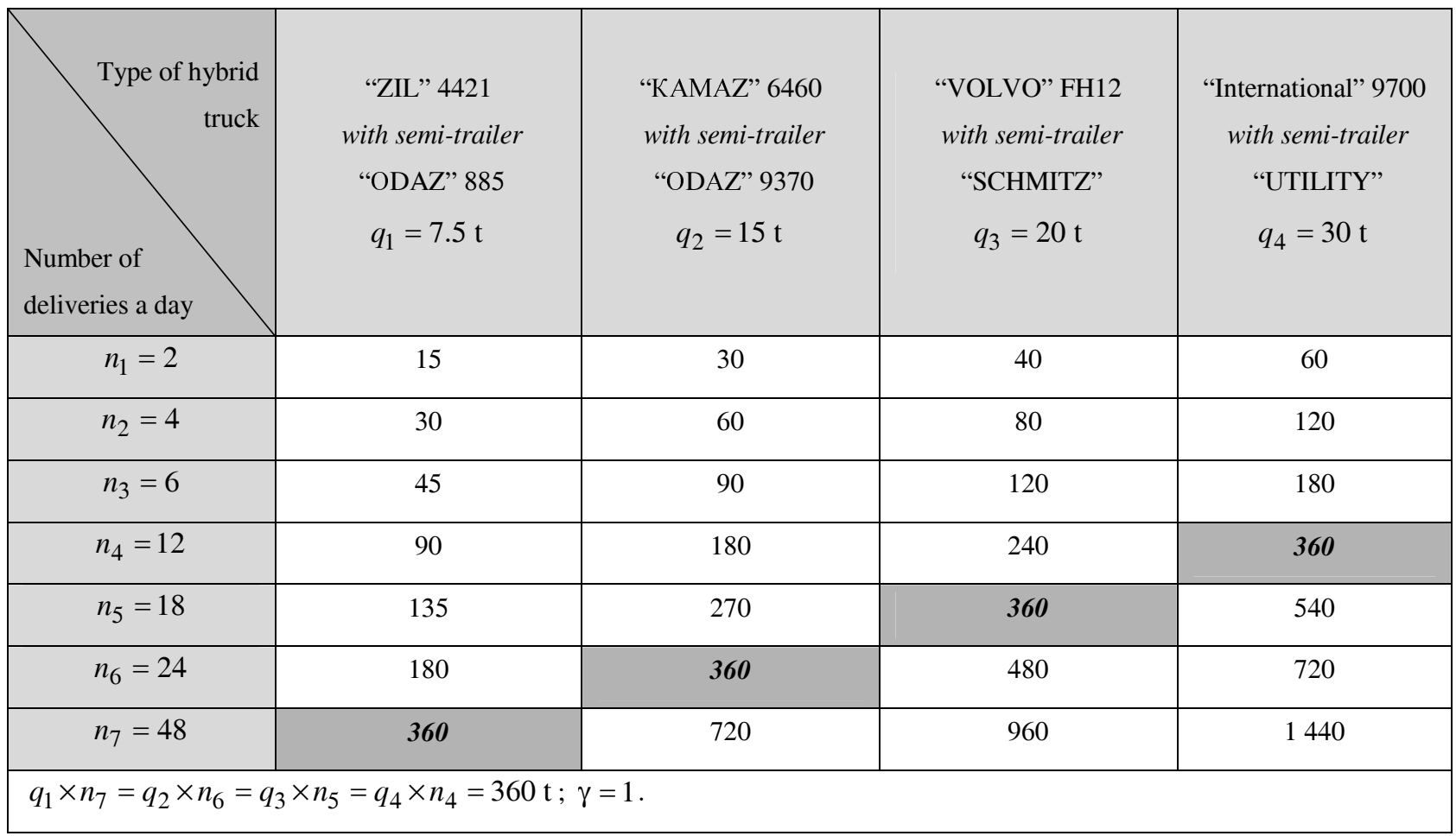




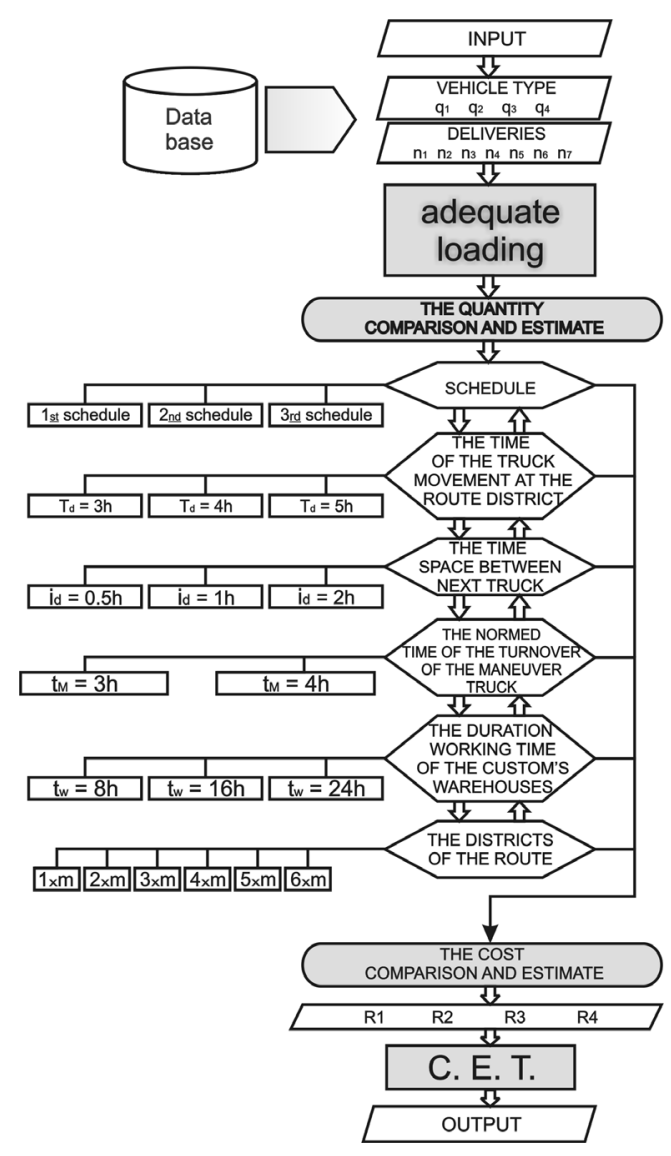

Fig 6. Economic-mathematical model for the choice of cost-effective truck (C. E. T)

For economic evaluation of this model optimum use could be made of the following formula:

$$
R=E+\varepsilon \cdot k
$$

where: $R$ - the total annual costs; $E$ - the operating costs/wages, fuel, maintenance, repair of rolling stock, renovation, depreciation, overhead costs; $\varepsilon-$ the rate of return $\varepsilon=\frac{1}{T} ; \varepsilon=0.2 ; \quad T$ - the pay-off period (5 years); $k$ - the investments (investments in the rolling stock, buildings, constructions, equipment, etc.).

\section{Logistics terminals}

The terminals are important links in the supply chain since just they are used at the beginning and end of freight delivery operations [4].

The following three key aspects should be highlighted in the operation of the terminals.

Firstly. The maneuvering turnaround of the truck $\left(t_{m}\right)$ is performed in the terminal zone. It includes the time required for detaching the semi-trailer from the line-haul truck and coupling it with the maneuvering truck, delivering the semi-trailer to the consignee, unloading, movement to the consigner, loading and return to the terminal. Sometimes the goods transfer operations may be dual: the consignee is the consigner.
Experience leads us to conclude that even in such a megalopolis as Moscow with very complicated urban traffic, as a rule, $t_{m}=3 \mathrm{~h}$ are quite enough.

To calculate the time of the maneuvering turnaround, use may be made of the formula:

$$
t_{m}=t_{c-r}+\frac{l_{t}}{\beta \cdot V_{T}}+t_{n-p}
$$

where: $t_{c-r}$ - the time required to change the truck; $l_{t}$ - the time of run to the freight owner; $\beta$ - the fullload run factor; $V_{T}$ - the average speed of truck movement; $t_{n-p}$ - the time of semi-trailer loading/unloading.

Secondly. Sometimes due to some reasons (prompt delivery, specific load, etc.) the line-haul trucks deliver the goods directly to the points of destination (the consignee), located before the next terminal ("under-run" of the trucks) or after the terminal ("over-run" of the truck) on the line-haul, or to the customers, located somewhere away from the main route. The imaginary line interconnecting these points, forms an area, used for maneuvering operations on it (see Fig 7).

Thirdly. Rhythmical operation of the terminal, when the frequency of trucks arrival corresponds to the transport capability of the terminal (availability of the sufficient amount of working places, grounds for detaching semi-trailers, no restrictions in the required area for truck maneuvers, etc.).

Let us illustrate it with such a simple example. There is a terminal with the grounds for changing semitrailers $(z=4)$ and maneuvering trucks $\left(A_{t}=12\right)$.

The interval of arrival of the maneuvering trucks is:

$$
J=\frac{t_{m}}{A_{T}}=\frac{3 \mathrm{~h}}{12}=15 \mathrm{~min} .
$$

The terminal operation rate is:

$$
\begin{aligned}
& R=\frac{t_{n-p}}{z}=\frac{1 \mathrm{~h}}{4}=15 \mathrm{~min} . \\
& J=R-\text { the condition of trouble-free operation of }
\end{aligned}
$$
the terminal;

$J>R-$ the grounds for changing semi-trailers are vacant;

$J<R-$ the dwell time of the trucks.

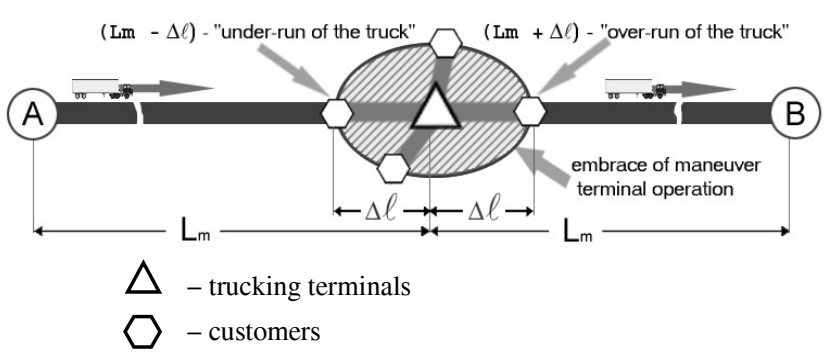

Fig 7. Logistics terminal 


\section{Experience of trucking operations in Russia}

The suggested Russian district trucking system is coordinated with the existing infrastructure and the available road network. For instance, the lengths of road sections are historically based on distances since the 18th century which were covered by horse carts during a day $(250-300 \mathrm{~km})$ and the present stations for changing the trailers are their natural modifications for the district trucking system. The new routes should be based on the mode of continuous truck traffic. This is the main factor determining the length of the road section. Thus, the cargo stations created at the joints of the sections not always coincided with the urban-centers. Local freight distribution is performed along special routes using the rolling stock of medium and small capacity.

Now let us discuss the social aspect of this problem. We have conducted the opinion survey of the drivers of five trucking companies providing interurban long haul service who article in different road, climatic and operating conditions (more than 800 long-rangers of the urban-centers have been subjected to questionnaire survey: in Moscow, St. Petersburg, N. Novgorod, Novosibirsk and Rostov-Don). The results of this survey show the following opinions about the district traffic system:

- $63 \%$ yes, useful;

- $12 \%$ no;

- $17 \%$ don't know;

- $8 \%$ maybe.

It is worthwhile mentioning that the system is actively supported by the drivers who are 20 to 30 years old $(84 \%)$.

The length of service age, length of service as a driver (both general and interurban), family structure and other factors were taken into account. Indeed, long trips and hard working conditions of truck drivers have a negative effect on their health and family situation. That is why the district trucking system was introduced in the regions with extremely difficult conditions in the Arctic North on the Kolyma route: "Magadan (Ohotskoe Sea) - Orotukan - Srednekolymsk - Chersky (1520 km) (Arctic Ocean)" with the author taking part as a driver. Mostly the route lies over the frozen Kolyma River (ice-snow road) [5]. Later this system was successfully used in the central region of Russia (Department of Motor Transport) and approved by the General Staff for operative transport of troops and military equipment (Ministry of Defence).

At the present time the stock of trucks for line-haul traffic is decentralized. The freight traffic based on the district system operating on the Moscow - Vladimir N. Novgorod route is rather symbolic than real. There is a lot of reasons for it: low technical level of the rolling stock, bad road conditions, schedule frustration, absence of communication radio sets and so on.

At the same time freight service based on the district system using the only Moscow - Tver - Bologoye - V. Novgorod - St. Petersburg highway $(615 \mathrm{~km})$ (for example) can produce an economic effect in the amount of 772.50 million rubles or nearly $\$ 27.7$ million annually (according to the most modest calculations, less transit and material losses of goods on the route withdrawn from calculation for the through system). Perhaps these data may seem unconvincing, but there are valid and detailed calculations, confirmed documentarily. By the way, the economic advantages of the district system can be calculated by the interested persons using another example. The economic effectiveness of the district trucking system is attained mostly due to reducing the rolling stock (up to $30 \%$ ) (of course, taking into account maneuvering trucks as well). Using the through trucking system and regular trucking operations on this "Moscow - St. Petersburg" highway the duration of the full truck turnaround will amount to $\Omega=72 \mathrm{~h}$ (i.e. a period of time from the truck departure from the depot till the next truck departure). The time required for long relaxation of the trucker on the route and for technical service of truck is included in the full turnaround period.

Since the time of the truck turnaround includes all calendar time of each unit of the rolling stock, after determining it, we can find the number of trucks per one departure a day (in the loaded direction), i.e. the truck leaving Moscow for St. Petersburg at $8 \mathrm{a}$. m. on Monday, will be on line-haul route again only at $8 \mathrm{a}$. $\mathrm{m}$. on Thursday, but the regular freight flow on the linehaul route demands everyday truck departure.

Thus, the number of trucks required for " $n$ " departures is:

$$
A_{T}=n \cdot k=3 \cdot n
$$

where $k-$ is the multiplicity coefficient of the day, $k=\frac{\Omega}{24}=3$ (let us remind, that at the district system in our instance $A_{T}=\frac{m \cdot n}{2}=2 \cdot n$, and the delivery of goods is accomplished during $24 \mathrm{~h}$ ).

\section{Conclusions}

1. The author suggests a new conceptual approach to the solution of the problem of interurban long haul service by use of road trains. This is a technology of the trucking operations between separate geographical regions based on the district trucking system. By the way this technology does not exclude the employment of the through trucking for small occasional and random freight flows [6]. The district trucking system is effective for heavy and regular freight flows. First of all, perfect labour management and relaxation routine are well organized in both systems. Furthermore, they are characterized by different operation time of the road trains on the route. For the through trucking system, the operation time of the truck with a semi-trailer does not exceed 10-12 hours a day, in compliance with the long haul service rules (recommended working conditions for such drivers). As for the district trucking system the operation time of a truck can amount to 16-18 hours a day and for a semi-trailer up to 20-22 hours. As a re- 
sult, the number of the rolling stock decreases and the productive run of every truck increases. Any doubts about the safety of the semi-trailers after changing the truck on the route are groundless since the location of each semi-trailer is checked by the special control service of the transportation company (truck owner) in the same way as it is done for the rail cars in the railway company. At the moment of changing the trucks both counter drivers in the presence of the control mechanic check the identification numbers, safety of freight and seal intactness against the certificate.

2. This article is the result of collection, processing and analysis of the extensive information on the enterprises constantly cooperating in the field of freight exchange making use of the interurban long haul service. The district trucking system is the way to the predictable planning of freight transportation based on the traffic schedule of the road trains which was implemented by other transportation means (railway, sea transport and air service) long ago [7].

3. The district trucking system is more effective for very-long-haul and transcontinental deliveries with considerable share of transit transport. Using the district trucking system, the trucking companies can choose any of the three suggested schedules relying on the available rolling stock, transportation abilities, tasks, aims and interests. When renewing their fleet, the trucking companies may give their demands and recommendations to the trucking industry so that necessary corrections are made in the production programme. The other issue for freight policy here is the possibility of the lowering highway congestion [8].

\section{References}

1. POCKLAD, O. Distribution of the regional freight flows (Распределение региональных грузопотоков). Moscow: Transport, 1995 (in Russian).

2. POCKLAD, O. Transport-economic connections of the separate regions (Транспортно-экономические связи отдельных регионов. Доклад). Report. Academy of Management. Moscow, 1998 (in Russian).

3. KOSTENKO, A.; POCKLAD, O.; CHEIDZE, N. Combined transport network of CIS (Единая транспортная сеть стран СНГ). Kiev: Transport and Communication, 1997 (in Russian).

4. SMEHOV, A. Framearticle of the transport logistics. marketing (Основы транспортной логистики. Маркетинг). Moscow, 1997 (in Russian).

5. POCKLAD, O.; SUVOROV, V. The organization of the traffic by long-distance trucks in the Extreme North. Transport Policy and Planning (Организация движения магистральными автопоездами на Крайнем Севере. Транспортная политика и планирование). Magadan, 1981 (in Russian).

6. TIHOMIROV, N. Theory of road trains. Textbook (Teoрия автопоездов. Учебник). Moscow: Science, 1984 (in Russian).

7. POCKLAD, O. Some regularities of long-haul freight traffic by road transport. (Некоторые закономерности дальнемагистрального грузового движения автотранспорта). Report. TRANSTEC ATHENS, Greece, 2004 (in Russian).
8. POCKLAD, O. Certain Regularities of interurban longhaul service with use of road trains. Report. Transportation Research Board 85-th annual international meeting (Определенные закономерности междугородного дальнемагистрального обслуживания с использованием автопоездов. Доклад на 85-й ежегодной Международной конференции Транспортного исследовательского совета). Washington, D.C. USA, 2006 (in Russian). 